\title{
PENGARUH Trichoderma spp. DALAM BEBERAPA JENIS BAHAN ORGANIK TERHADAP PENYAKIT BULAI (Peronosclerospora spp.)
}

\section{EFFECT OF Trichoderma spp. IN SOME TYPES OF ORGANIC MATERIALS ON THE DOWNY MILDEW DISEASE (Peronosclerospora spp.)}

\author{
Pratiwi Iswari*, Joko Prasetyo, Muhammad Nurdin, Suskandini Ratih Dirmawati \\ Jurusan Agroteknologi, Fakultas Pertanian, Universitas Lampung \\ Jl Sumantri Brojonegoro 1, Bandar Lampung 35145, Indonesia \\ *Email:pratiwi.iswari@gmail.com
}

\begin{abstract}
Downy mildew disease caused by the fungus Peronosclerospora spp. is a disease that becomes a limiting factor for maize crop production because the impact of downy mildew attacks can reduce production by up to $90 \%$. Control of downy mildew by using a fungicide made from metalaxyl is now ineffective so it requires other controls that are more environmentally friendly such as using biological agents Trichodema spp. and some organic ingredients in lieu of synthetic fungicides. This research was conducted to find out the suitable organic material for growing media Trichoderma spp. in inducing plant resistance to downy mildew. This research was conducted in the Laboratory of Plant Pests and Diseases at the Faculty of Agriculture, University of Lampung from May to July 2019. The treatments were arranged in a Randomized Block Design (RBD) with 5 treatments, namely: P0 $=$ control (soil), $\mathrm{P} 1=$ soil and sawdust by comparison $2: 1, \mathrm{P} 2=$ soil and bran with a ratio of 2: 1, P3 = soil and husk with a ratio of $2: 1, \mathrm{P} 4=$ soil and media mixture consisting of sawdust, bran, and husk in a ratio of 2: 1: 1: 1. The results showed that the administration of Trichoderma spp. and several organic materials namely husks, bran, and sawdust significantly suppress the occurrence of downy mildew at 11 to $13 \mathrm{hsi}$, slow the incubation period, and increase plant height and dry weight of maize.
\end{abstract}

Keywords: Erosion, organonitrofos fertilizer, soil conservation.

\begin{abstract}
ABSTRAK
Penyakit bulai yang disebabkan oleh jamur Peronosclerospora spp. merupakan penyakit yang menjadi faktor pembatas produksi tanaman jagung karena dampak dari serangan bulai dapat menurunkan produksi hingga 90\%. Pengendalian penyakit bulai dengan menggunakan fungisida berbahan aktif metalaksil saat ini sudah tidak efektif sehingga diperlukan pengendalian lain yang lebih ramah lingkungan seperti menggunakan agen hayati Trichodema spp. dan beberapa bahan organik sebagai pengganti dari fungisida sintesis. Penelitian ini dilakukan untuk mengetahui bahan organik yang cocok untuk media tumbuh Trichoderma spp. dalam menginduksi ketahanan tanaman melawan penyakit bulai. Penelitian ini dilakukan di lingkungan Laboratorium Hama dan Penyakit Tumbuhan Fakultas Pertanian Universitas Lampung sejak bulan Mei hingga Juli 2019. Perlakuan disusun dalam Rancangan Acak Kelompok (RAK) dengan 5 perlakuan yaitu: P0 = kontrol (tanah), P1 = tanah dan serbuk gergaji dengan perbandingan $2: 1, \mathrm{P} 2=$ tanah dan dedak dengan perbandingan $2: 1, \mathrm{P} 3=$ tanah dan sekam dengan perbandingan 2:1, P4 = tanah dan campuran media terdiri dari serbuk gergaji, dedak, dan sekam dengan
\end{abstract}


perbandingan 2:1:1:1. Hasil penelitian menunjukkan bahwa pemberian perlakuan Trichoderma spp. dan beberapa bahan organik yaitu sekam, dedak, dan serbuk gergaji menekan secara nyata terhadap keterjadian penyakit bulai pada 11 hingga 13 hsi, memperlambat masa inkubasi, dan meningkatkan tinggi tanaman serta bobot kering berangkasan jagung.

Kata kunci: Bulai, Trichoderma spp., sekam, dedak, serbuk gergaji.

\section{PENDAHULUAN}

Jagung merupakan tanaman yang cukup populer di Indonesia karena merupakan sumber karbohidrat kedua setelah beras. Jagung juga mempunyai arti penting dalam pengembangan industri di Indonesia karena merupakan bahan baku untuk industri pangan maupun pakan ternak. Permintaan jagung dari tahun ke tahun terus meningkat seiring dengan berkembangnya usaha peternakan dan industri pangan. Namun demikian perkembangan produksi jagung di dalam negeri belum mampu mengimbangi perkembangan permintaan tersebut.

Dalam budidaya tanaman jagung ditemukan banyak kendala yang dapat menurunkan produksi tanaman jagung. Salah satu kendala yang dihadapi petani adalah rendahnya ketahanan tanaman jagung terhadap hama dan penyakit. Salah satu penyakit yang menjadi faktor pembatas produksi tanaman jagung yaitu penyakit bulai (Peronosclerospora spp.). Menurut Semangun (2004) dampak penyakit bulai dapat menurunkan produksi tanaman jagung hingga mencapai 90\%. Kerusakan tersebut sangat merugikan petani sehingga perlu dilakukan pengendalian.

Fungisida sintesis sampai saat ini masih sering digunakan untuk mengendalikan penyakit bulai oleh petani. Fungisida sintesis ini berbahan aktifmetalaksil yang diaplikasikan sebagai perlakuan benih. Fungisida berbahan aktif metalaksil pada tahun 1980-an masih efektif mengendalikan penyakit bulai (Wakman dan Said, 1986). Di Indonesia hingga saat ini penggunaan fungisida metalaksil telah berjalan lebih dari 20 tahun, sejak tahun 1980-an (Jasis dkk, 1981). Fungisida sintesis yang di-aplikasikan secara terus menerus dalam waktu lama dapat menimbulkan terjadinya resistensi pada jamur patogen bulai (Surtikanti, 2013).

Salah satu teknik yang dapat digunakan untuk mengendalikan penyakit bulai adalah dengan menggunakan pemanfaatan agen hayati (biofungisida) sebagai pengganti pestisida sintesis dengan menggunakan jamur Trichoderma spp. Beberapa penyakit tanaman sudah dapat dikendalikan dengan menggunakan jamur Trichoderma spp. diantaranya adalah busuk pangkal batang pada tanaman panili yang disebabkan oleh jamur Fusarium sp. dan Jamur Akar Putih (JAP) yang menyerang tanaman karet. Potensi jamur Trichoderma spp. sebagai jamur antagonis, selain itu diketahui pula bahwa Trichoderma spp.juga berfungsi sebagai dekomposer dalam pembuatan pupuk organik.

Salah satu cara pengendalian yang perlu diperhatikan dan dikembangkan adalah dengan meningkatkan ketahanan tanaman terhadap serangan patogen menggunakan agensia hayati. Hal tersebut 
dikenal sebagai mekanisme induksi ketahanan sistemik. Induksi ketahanan sistemik atau induced systemic resistance (ISR) merupakan peningkatan ketahanan tanaman yang dikembangkan tanaman karena adanya rangsangan yang sesuai. Mekanisme itu secara normal berfungsi membatasi pertumbuhan dan penyebaran patogen. Efektivitas mekanisme ini dapat ditingkatkan oleh agen penginduksi dan pemacu pertumbuhan berupa agensia hayati.

Salah satu cara untuk meningkatkan kemampuan jamur antagonis adalah menumbuhkannya atau memperbanyak pada media yang tepat. Media yang sering digunakan saat ini untuk perbanyakan Trichoderma spp. adalah media beras dan jagung tetapi media tersebut untuk perbanyakan secara massal memerlukan biaya yang relatif tinggi. Untuk itu diperlukan suatu media alternatif baru yang dapat digunakan sebagai media biakan yang memiliki nilai ekonomi rendah, cukup nutrisi, efektif dan mudah didapatkan, ketersediaan bahan baku berlimpah dan dapat dimanfaatkan oleh Trichoderma spp. untuk tumbuh dan berkembang. Berdasarkan hal-hal tersebut terdapat beberapa masalah yang mendasari penelitian ini yaitu adakah bahan organik yang cocok sebagai media tumbuh Trichoderma spp. dalam menginduksi ketahanan jagung melawan penyakit bulai.

\section{BAHAN DAN METODE}

Waktu dan tempat. Penelitian ini telah dilakukan pada bulan Mei hingga Juli 2019 di Laboratorium Hama dan Penyakit Tanaman Jurusan Agroteknologi, Fakultas Pertanian Universitas Lampung.

Pelaksanaan penelitian. Penelitian disusun dengan Rancangan Acak Kelompok (RAK) dengan 5 perlakuan yaitu: $\mathrm{P} 0=\operatorname{kontrol}(\tan a h), \mathrm{P} 1=\tan a h$ dan serbuk gergaji dengan perbandingan $2: 1, \mathrm{P} 2=$ tanah dan dedak dengan perbandingan 2:1, P3 = tanah dan sekam dengan perbandingan $2: 1, \mathrm{P} 4=$ tanah dan campuran media terdiri dari serbuk gergaji, dedak,dan sekam dengan perbandingan $2: 1: 1: 1$. Perlakuan tersebut diulang sebanyak 6 ulangan.

Persiapan media tanam. Media tanam yang digunakan adalah tanah yang diambil di sekitar Laboratorium Hama dan Penyakit Tanaman, Jurusan Agroteknologi, Fakultas Pertanian, Universitas Lampung dan dicampur dengan serbuk gergaji, dedak, sekam, campuran dari serbuk gergaji, dedak, sekam dengan perbandingan 2:1. Tanah, sekam, serbuk gergaji, dan dedak disterilkan secara terpisah dengan menggunakan tungku selama 3 jam pada suhu $100 \mathrm{p} \mathrm{C}$ dan tekanan normal. Setelah itu tanah, sekam, serbuk gergaji dan dedak tersebut dimasukkan kedalam polibag berukuran $10 \mathrm{~kg}$ sesuai dengan perlakuan yang digunakan.

Perbanyakan isolat Trichoderma spp. Perbanyakan isolat Trichoderma spp. dilakukan di Laboratorium Penyakit Tanaman. Isolat Trichoderma spp. diperoleh dari Klinik Tanaman Universitas Lampung. Jamur tersebut diisolasi ke dalam media PSA (Potato Sucrose Agar) baru dalam cawan petri. Perbanyakan isolat Trichoderma spp. tersebut dilakukan dengan mengambil biakan menggunakan jarum ose kemudian dipindahkan ke media PSA baru dan diinkubasi selama tujuh hari.

Penanaman tanaman jagung. Benih jagung yang digunakan adalah benih jagung varietas Pioner 27 (P27). Benih dicuci untuk menghilangkan fungisida 


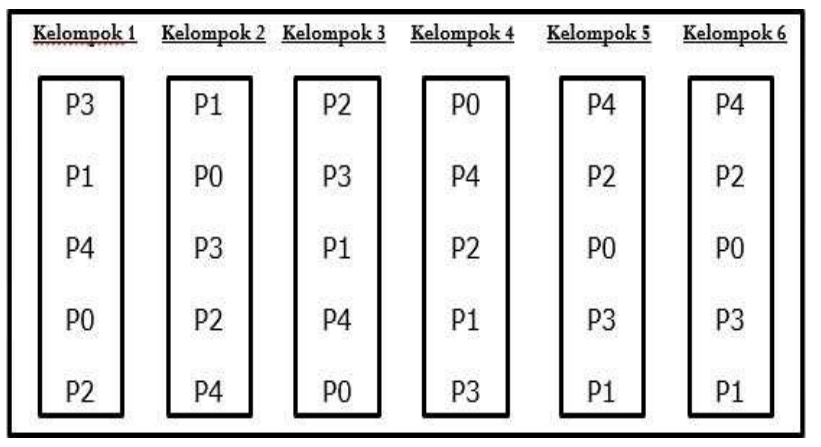

Gambar 1. Tata letak percobaan.

kemudian ditanam pada polibag dengan ukuran $10 \mathrm{~kg}$ sebanyak 10 benih per polibag. Jumlah polibag yang digunakan yaitu 30 polibag dan dilakukan tindakan pemeliharaan berupa penyiraman.

Aplikasi Trichoderma spp. Trichoderma spp. yang telah diperbanyak disuspensikan dengan menggunakan air steril sebanyak $100 \mathrm{ml}$ dan selanjutnya dipindahkan dalam erlenmeyer kemudian dihomogenkan dengan menggunakan rotary mixer lalu diencerkan dengan tiga kali tahap pengenceran. Kerapatan spora Trichoderma spp. dihitung dengan menggunakan hemositometer sebelum diaplikasikan pada tanaman. Suspensi Trichoderma spp diaplikasikan dengan kerapatan $10^{8} \mathrm{spora} / \mathrm{ml}$. Aplikasi Trichoderma spp. dilakukan dengan cara menyiramkan suspensi Trichoderma spp. tersebut ke dalam rizosfer tanaman yang berumur 5 hst dengan dosis sebanyak 10 ml per tanaman pada pukul 06.00 WIB.

Penyiapan suspensi spora Peronosclerospora spp. Tanaman jagung yang terkena bulai diletakkan pada nampan yang diisi air dan di letakkan di dalam ruangan bersuhu 17! pada pukul 17:00 WIB. Spora jamur diambil pagi hari pukul 04:00 WIB dengan cara memberikan air steril pada permukaan bawah 5 helai daun yang sakit kemudian diserut dengan menggunakan kuas supaya spora yang terbawa air dapat langsung masuk ke gelas ukur yang telah disiapkan kemudian dihomogenkan dengan pengaduk.

Inokulasi Peronosclerospora spp. Inokulasi dilakukan dengan cara meneteskan suspensi spora Peronosclerospora spp. pada titik tumbuh tanaman uji yang berumur $10 \mathrm{HST}$ sebanyak $1 \mathrm{ml}$ per tanaman. Inokulasi dilakukan pada pukul 04.30 WIB.

Pengamatan dan pengumpulan data.

Pengamatan dilakukan setiap hari selama 4 minggu. Variabel yang diamati adalah keterjadian penyakit, masa inkubasi, tinggi tanaman, bobot kering.

\section{Variabel Pengamatan}

Masa inkubasi. Masa inkubasi merupakan waktu yang dibutuhkan tanaman untuk sakit yang dihitung sejak inokulai penyakit hingga muncul gejala.

Keterjadian penyakit. Keterjadian penyakit dihitung dengan rumus (Ginting, 2013) :

$$
\mathrm{Kp}=\frac{\mathrm{n}}{\mathrm{N}} \times 100 \%
$$

Keterangan :

Kp : keterjadian penyakit (\%)

$\mathrm{n} \quad$ : jumlah unit tanaman terserang

$\mathrm{N} \quad$ :jumlah unit tanaman diamati

Pertumbuhan tanaman. Pertumbuhan tanaman yang diamati adalah tinggi tanaman, bobot basah dan bobot kering tanaman. Tinggi tanaman akan diukur mulai dari permukaan tanah hingga ujung daun tertinggi tanaman dengan penggaris. Pengamatan bobot basah dan bobot kering tanaman dilakukan setelah tanaman berumur 35 HST. Bobot tanaman ditimbang dengan menggunakan timbangan duduk, kemudian dioven pada suhu $70^{\circ}$ selama 36 jam sampai bobot konstan. 


\section{HASIL DAN PEMBAHASAN}

Hasil penelitian membuktikan bahwa perlakuan pemberian Trichoderma spp. dan beberapa bahan organik yaitu sekam, dedak, dan serbuk gergaji berpengaruh nyata terhadap keterjadian penyakit bulai pada 11 hingga 13 hsi, memperlambat masa inkubasi, dan meningkatkan tinggi tanaman serta bobot kering berangkasan jagung.

Gejala penyakit bulai muncul saat 7 hsi (hari setelah inokulasi) yaitu pada saat tanaman jagung berumur 17 hst (hari setelah tanaman) pada P0, P1, P2, P3, dan P4. Pada saat tanaman jagung berumur 14 hsi sudah tidak ada tanaman jagung yang terserang patogen bulai. Gejala awal yang terlihat adalah munculnya garis-garis berwarna putih yang sejajar dengan tulang daun dan kemudian menjalar ke seluruh permukaan daun. Pada bagian bawah daun yang terserang, terdapat tanda jamur patogen bulai yang berbentuk seperti tepung berwarna putih.

Masa inkubasi. Berdasarkan uji analisis ragam perlakuan Trichoderma spp. dan beberapa bahan organik terbukti mampu memperlambat masa inkubasi penyakit bulai pada tanaman jagung. Uji lanjut BNT pada taraf 5\% menunjukkan jika perlakuan Trichoderma spp. dan beberapa bahan organik memiliki kemampuan yang sama dalam memperlambat masa inkubasi penyakit bulai pada tanaman jagung. Tabel 1 menjelaskan bahwa pemberian Trichoderma spp. dan beberapa bahan organik mampu memperlambat masa inkubasi penyakit bulai pada tanaman jagung. Pada uji lanjut BNT 5\% P1, P2, P3, dan P4 mampu memperlambat masa inkubasi penyakit bulai pada tanaman jagung lebih baik dari P0.

Perlakuan Trichoderma spp. dan beberapa bahan organik yaitu Trichoderma spp + serbuk gergaji, Trichoderma spp. + dedak, Trichoderma spp. + sekam, dan Trichoderma spp. + serbuk gergaji + dedak + sekam memiliki kemampuan yang lebih baik dalam memperlambat masa inkubasi penyakit bulai tanamanjagung. Menurut penelitian Yulia, dkk(2017), perlakuan Trichoderma sp. dengan isolat nenas, bawang, dan jahe mampu menunda masa inkubasi penyakit akar gada oleh jamur Plasmodiophora brassicae pada tanaman caisin sebesar 27,51\%, $26,65 \%$, dan $24,33 \%$. Hal tersebut didukung oleh pernyataan Prabowo, dkk (2006), yang menyatakan bahwa terjadinya persaingan antara patogen dengan jamur antagonis akan menyebabkan patogen membutuhkan waktu yang lebih lama untuk menginfeksi tanaman karena sistem akar tanaman didominasi oleh

Tabel 1. Masa inkubasi penyakit bulai (hari) pada tanaman jagung yang telah diberi perlakuan Trichoderma spp dan beberapa bahan organik

\begin{tabular}{lc}
\hline \multicolumn{1}{c}{ Perlakuan } & Masa Inkubasi (hari) \\
\hline P0 (kontrol) & $11,06 \mathrm{~b}$ \\
P1 (Trichoderma spp. + serbuk gergaji) & $13,03 \mathrm{a}$ \\
P2 (Trichoderma spp. + dedak) & $13,64 \mathrm{a}$ \\
P3 (Trichoderma spp. + sekam) & $13,11 \mathrm{a}$ \\
P4 (Trichoderma spp. + serbuk gergaji + dedak + sekam) & $12,28 \mathrm{a}$ \\
\hline BNT 5\% & 1,56 \\
\hline
\end{tabular}

Keterangan: Angka dalam kolom yang diikuti huruf yang sama tidak berbeda nyata menurut Uji BNT 5\% 
antagonis sehingga terjadi penundaan masa inkubasi. Trichoderma spp. menghasilkan enzim 1,3-âglukanase dimana enzim tersebut akan mendegradasi dan menghidrolisis dinding sel miselium jamur patogen tanaman sehingga membantu tanaman dalam melawan patogen (Yulia dkk, 2017). Mekanisme antagonis jamur Trichoderma spp. dalam menekan patogen bulai disebabkan karena adanya kompetisi ruang tumbuh dan nutrisi, interaksi sistem hifa dan mekanisme antibiosis.

Keterjadian penyakit bulai. Berdasarkan data hasil penelitian, perlakuan Trichoderma spp. dan beberapa bahan organik yang diaplikasikan pada rizosfer tanaman jagung dapat menghambat serangan patogen bulai sehingga menekan keterjadian penyakit bulai. Berdasarkan analisis ragam, pemberian Trichoderma spp. dan beberapa bahan organik dapat menekan keterjadian penyakit bulai tanaman jagung pada 11 hingga 13 hsi. Uji lanjut BNT pada taraf 5\% menunjukkan jika perlakuan Trichoderma spp. dan beberapa bahan organik memiliki kemampuan yang sama dalam menekan keterjadian penyakit bulai tanaman jagung pada 11 hingga 13 hsi. Tabel 2 menjelaskan bahwa pemberian Trichoderma spp. dan beberapa bahan organik mampu menekan keterjadian penyakitbulai sejak 11 hingga 13 hsi. Berdasarkan uji lanjut BNT pada taraf 5\%, pada 11 hingga 13 hsi perlakuan $\mathrm{P} 1$, P2, P3, dan P4 mampu menekan keterjadian penyakit bulai lebih baik dibandingkan dengan perlakuan P0.

Perlakuan Trichoderma spp. dan beberapa bahan organik yaitu Trichoderma spp + serbuk gergaji, Trichoderma spp. + dedak, Trichoderma spp. + sekam, dan Trichoderma spp. + serbuk gergaji + dedak + sekam memiliki pengaruh yang sama dan lebih baik dari perlakuan kontrol dalam menekan penyakit bulai. Hal ini didukung dengan penelitian Yulia, dkk (2017) yang menyatakan bahwa pemberian Trichoderma spp. dalam kompos mampu menekan keterjadian penyakit jamur akar putih yang disebabkan oleh jamur Rigidoporus lignosus pada tanaman karet. Menurut penelitian Berlian, dkk (2013) Trichoderma harzianum dan Trichoderma hamatum terbukti efektif dalam mengendalikan jamur Rigidoporus microporus dengan persentase penghambatan sebesar $81,85 \%$. Soenartiningsih, dkk (2014) menyatakan bahwa Trichoderma spp. tidak dapat mematikan

Tabel 2. Keterjadian penyakit bulai pada tanaman jagung yang telah diberi perlakuan Trichoderma spp dan beberapa bahan organik

\begin{tabular}{|c|c|c|c|c|c|c|c|}
\hline \multirow{2}{*}{ Perlakuan } & \multicolumn{7}{|c|}{ Keterjadian Penyakit (\%) } \\
\hline & $7 \mathrm{hsi}$ & $8 \mathrm{hsi}$ & 9 his & 10 hsi & $11 \mathrm{hsi}$ & $12 \mathrm{hsi}$ & $13 \mathrm{hsi}$ \\
\hline P0 & $22,22 \mathrm{tn}$ & $27,78 \mathrm{tn}$ & $33,33 \mathrm{tn}$ & $36,11 \mathrm{tn}$ & $47,22 \mathrm{a}$ & $61,11 \mathrm{a}$ & $63,89 \mathrm{a}$ \\
\hline $\mathrm{P} 1$ & $5,56 \mathrm{tn}$ & 8,33 th & $11,11 \mathrm{tn}$ & $13,89 \mathrm{tn}$ & $19,44 \mathrm{~b}$ & $19,44 \mathrm{~b}$ & $19,44 \mathrm{~b}$ \\
\hline $\mathrm{P} 2$ & $2,78 \mathrm{tn}$ & $5,56 \mathrm{tn}$ & $5,56 \mathrm{tn}$ & $5,56 \mathrm{tn}$ & $5,56 \mathrm{~b}$ & $5,56 \mathrm{~b}$ & $5,56 b$ \\
\hline P3 & $5,56 \mathrm{tn}$ & $13,89 \mathrm{tn}$ & $13,89 \mathrm{tn}$ & $13,89 \mathrm{tn}$ & $13,89 \mathrm{~b}$ & $13,89 \mathrm{~b}$ & $13,89 \mathrm{~b}$ \\
\hline $\mathrm{P} 4$ & $5,56 \mathrm{tn}$ & 19,44 tn & 19,44 th & $22,22 \mathrm{tn}$ & $22,22 \mathrm{~b}$ & $22,22 \mathrm{~b}$ & $22,22 \mathrm{~b}$ \\
\hline BNT $(5 \%)$ & - & - & - & - & 23,5 & 25,58 & 24,81 \\
\hline
\end{tabular}

Keterangan: Angka dalam kolom yang diikuti huruf yang sama tidak berbeda nyata menurut Uji BNT 5\%. P0 = Kontrol, $\mathrm{P} 1=$ Trichoderma spp. + serbuk gergaji, $\mathrm{P} 2=$ Trichoderma $\mathrm{spp} .+$ dedak, $\mathrm{P} 3=$ Trichoderma $\mathrm{spp} .+$ sekam, $\mathrm{P} 4=$ Trichoderma spp. + serbuk gergaji + dedak + sekam 
patogen hanya menekan perkembangan patogen sehingga masih terdapat keterjadian penyakit namun lebih rendah dari perlakuan kontrol.

Tinggi tanaman. Uji analisis ragam perlakuan Trichoderma spp. dan beberapa bahan organik terbukti berpengaruh nyata terhadap tinggi tanaman jagung. Berdasarkan uji lanjut BNT pada taraf $5 \%$, perlakuan Trichoderma spp. dan beberapa bahan organik memiliki kemampuan yang sama dalam meningkatkan tinggi tanaman jagung. Tabel 3 menunjukkan bahwa pemberian Trichoderma spp. dan beberapa bahan organik mampu meningkatkan tinggi tanaman jagung. Pada uji lanjut BNT 5\% P1, P2, P3, dan P4 memiliki kemampuan yang lebih baik dalam meningkatkan tinggi tanaman.

Perlakuan Trichoderma spp. dan beberapa bahan organik yaitu Trichoderma spp + serbuk gergaji, Trichoderma spp. + dedak, Trichoderma spp. + sekam, dan Trichoderma spp. + serbuk gergaji + dedak + sekam memiliki kemampuan yang lebih baik dalam meningkatkan tinggi tanaman dan bobot kering berangkasan jagung dari pada kontrol. Hal ini sesuai dengan pernyataan Cornejo, dkk (2009), Trichoderma sp. menghasilkan auksin diantaranya adalah IAA hormon tersebut dapat meningatkan pertumbuhan akar lateral, memperbanyak tunas, serta
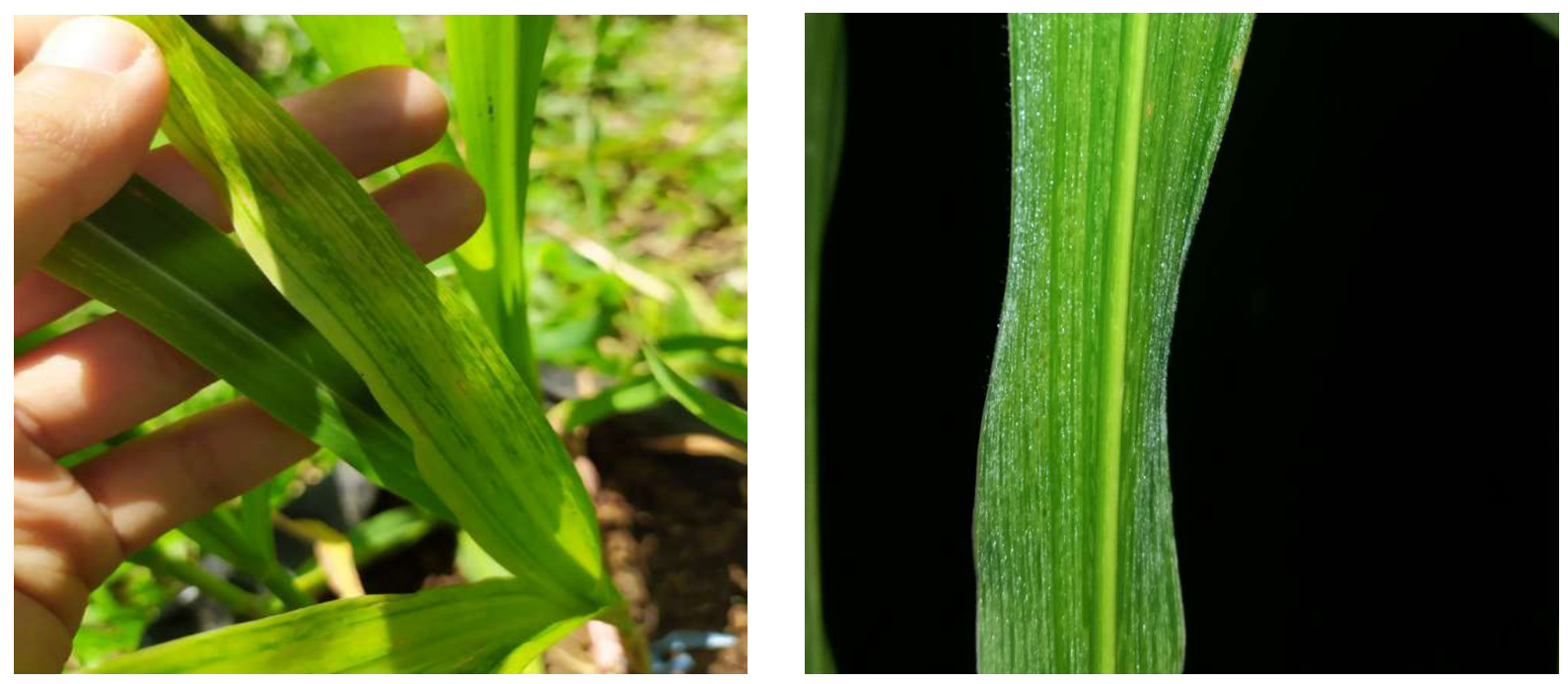

Gambar 2. a) Gejala penyakit bulai pada tanaman jagung, b) Tanda penyakit bulai di bagian bawah daun .

Tabel 3. Tinggi tanaman jagung yang telah diberi perlakuan Trichoderma spp dan beberapa bahan organik

\begin{tabular}{ccccc}
\hline \multirow{2}{*}{ Perlakuan } & \multicolumn{4}{c}{ Tinggi Tanaman $(\mathrm{cm})$} \\
\cline { 2 - 5 } & Minggu 1 & Minggu 2 & Minggu 3 & Minggu 4 \\
\hline P0 & $9,29 \mathrm{~b}$ & $15,43 \mathrm{~b}$ & $20,85 \mathrm{~b}$ & $27,04 \mathrm{~b}$ \\
P1 & $14,09 \mathrm{a}$ & $29,3 \mathrm{a}$ & $33,68 \mathrm{a}$ & $38,64 \mathrm{a}$ \\
P2 & $13,98 \mathrm{a}$ & $29,62 \mathrm{a}$ & $32,15 \mathrm{a}$ & $38,08 \mathrm{a}$ \\
P3 & $14,37 \mathrm{a}$ & $29,4 \mathrm{a}$ & $37,42 \mathrm{a}$ & $42,33 \mathrm{a}$ \\
P4 & $14,28 \mathrm{a}$ & $27,33 \mathrm{a}$ & $33,83 \mathrm{a}$ & $39,13 \mathrm{a}$ \\
\hline BNT (5\%) & 2,4 & 7,71 & 6,89 & 7,01 \\
\hline
\end{tabular}

Keterangan: Angka dalam kolom yang diikuti huruf yang sama tidak berbeda nyata menurut Uji BNT 5\% 
Tabel 4. Bobot kering berangkasan tanaman jagung yang telah diberi perlakuan Trichoderma spp dan beberapa bahan organik

\begin{tabular}{|c|c|}
\hline Perlakuan & Bobot Kering Berangkasan Jagung (g) \\
\hline P0 (kontrol) & $2,38 \mathrm{~b}$ \\
\hline P1 (Trichoderma spp. + serbuk gergaji) & $5,28 \mathrm{a}$ \\
\hline P2 (Trichoderma spp. + dedak) & $5,24 \mathrm{a}$ \\
\hline P3 (Trichoderma spp. + sekam) & $6,2 \mathrm{a}$ \\
\hline $\mathrm{P} 4$ (Trichoderma spp. + serbuk gergaji + dedak + sekam) & $5,29 \mathrm{a}$ \\
\hline BNT 5\% & 2,33 \\
\hline
\end{tabular}

Keterangan: Angka dalam kolom yang diikuti huruf yang sama tidak berbeda nyata menurut Uji BNT 5\%

meningkatkan biomassa tanaman. Selain itu menurut Haryuni (2013), Trichoderma spp. memiliki kemampuan menghidrolisis selulosa dan hemiselulosa menjadi glukosa dan xylosa sehingga meningkatkan biomassa tanaman.

Bobot kering berangkasan. Berdasarkan uji analisis ragam, perlakuan Trichoderma spp. dan beberapa bahan organik terbukti berpengaruh nyata terhadap bobot kering berangkasan tanaman jagung. Berdasarkan uji lanjut BNT pada taraf 5\%, perlakuan Trichoderma spp. dan beberapa bahan organik memiliki kemampuan yang sama dalam meningkatkan bobot kering berangkasan tanaman jagung. Tabel 4 menunjukkan bahwa pemberian Trichoderma spp. dan beberapa bahan organik mampu meningkatkan bobot kering berangkasan tanaman jagung. Serta pada uji lanjut BNT 5\% P1, P2, P3, dan P4 memiliki kemampuan yang lebih baik dalam meningkatkan bobot kering berangkasan jagung.

Bahan organik serbuk gergaji, dedak, dan sekam terbukti mampu mendukung pertumbuhan Trichoderma spp. Hal tersebut sesuai dengan penelitian Gusnawaty, dkk (2017) yang menyatakan bahwa presentase Trichoderma spp. pada media tumbuh sekam, dedak, dan serbuk gergaji saat 5 hsi (hari setelah inokulasi) yaitu 100\%. Menurut Uruilal, dkk (2012) dedak memiliki kandungan karbohidrat $27,01 \%$, serat kasar $0,48 \%, \mathrm{~N} 0,65 \%, \mathrm{P} 0,69 \%$, K 1,92\%, pH 6,16\%, kadar air 16,08\%. Sekam memiliki kandungan karbohidrat 15,39\%, serat kasar 0,42\%, N 1,68\%, P 0,59\%, K 0,59\%, kadar air 12,42\%. Menurut Nugraha dan Setyawati (2003), sekam padi memiliki kandungan karbohidrat 33,17, serat 35,68\%, hidrogen 1,54\%, karbon (zat arang) 1,33\%, abu $17,71 \%$, lemak 1,18\%, protein 3,03\%, kadar air 9,02\%. Selain itu, menurut Pusat Penelitian dan Perkembangan Perkebunan (2011), menyatakan bahwa jamur Trichoderma spp. memerlukan glukosa sebagai sumber karbon utama untuk pertumbuhannya. Berdasarkan pernyataan tersebut maka bahan organik yaitu serbuk gergaji sekam, dan dedak memiliki karbohidrat yang dapat diurai menjadi glukosa yang merupakan sumber nutrisi utama untuk pertumbuhan jamur Trichoderma spp.

\section{KESIMPULAN}

Berdasarkan penelitian yang telah dilakukan dapat disimpulkan bahwa perlakuan Trichoderma spp. 
dan beberapa bahan organik dapat menekan keterjadian penyakit bulai, memperlambat masa inkubasi penyakit bulai, serta meningkatkan tinggi tanaman dan bobot kering berangkasan jagung, namun antar perlakuan bahan organik tersebut memiliki pengaruh yang sama.

\section{DAFTAR PUSTAKA}

Berlian, I., Setyawan, B., Hadi, H. 2013. Mekanisme Antagonisme Trichoderma spp. terhadap Beberapa Patogen Tular Tanah. Warta perkaretan, Sungei putih. 32(2):74-82.

Cornejo, H. A. C., Rodriguez, L. M., Penagos, C. C., dan Bucio, C. L. 2009. Trichodermavirens a Plant Benefical Fungus, Nhancesbiomass Production and Promotes Lateral Root Grouth Trough an Auxin-Dependent Mecanism in Arabidopsiss. Plant Fisiologi 14(9):1579-159.

Ginting, C. 2013. Ilmu Penyakit Tumbuhan Konsep dan Aplikasi. Lembaga Penelitian Universitas Lampung. Lampung.

Gusnawaty, H. S., Taufik, M., Bande, L. O. S., dan Asis, A. 2017. Efektivitas Beberapa Media untuk Perbanyakan Agens Hayati Trichoderma sp. Jurnal HPT Tropika 17 (1): 70-76.

Haryuni. 2013. Perbaikan Pertumbuhan dan Hasil Stevia Melalui Aplikasi Trichoderma sp. Biosaintifika 5(2):58-63.

Jasis, S. Alimoeso, dan Hamid, A. W. 1981. Beberapa Hasil Pengujian Pengendalian Penyakit Bulai pada Tanaman Jagung 1979-1981. Makalah disajikan pada Kongres Nasional PFI ke VI Bukitinggi, 11-13 Mei. 9 hal.

Nugraha, S. dan Setyawati, J. 2003. Peluang Agribisnis Arang Sekam, Warta Litbang Pertanian Indonesia, Balai Penelitian Pascapanen Pertanian, vol 25 no 4, 1-2

Prabowo, A. K. E., Prihatiningsih, N., dan Soesanto, L. 2006. Potensi Trichoderma harzianum dalam mengendaikan 9 isolat Fusarium oksisporum schlecht.f. sp. Zingiberi Trujillo pada Kencur. Jurnal Ilmu-Ilmu Pertanian Indonesia 8(2):76-84.

Pusat Penelitian dan Perkembangan Perkebunan. 2014. Pengendalian Penyakit Jamur Akar Putih (JAP) Pada Pembibitan Karet dengan Trichoderma sp. Http://perkebunan.litbang.pertanian.go.id. Diakses pada 24 Juli 2019.

Semangun, H. 2004. Penyakit-penyakit Tanaman Perkebunan di Indonesia. UGM Press. Yogyakarta. $835 \mathrm{hlm}$.

Soenartingsih., Djaenuddin, N., dan Saenong, M.S. 2014. Efektivitas Trichoderma sp. dan Gliocladio sp. Sebagai Agen Biokontrol Hayati Penyakit Busuk Pelepah Daun pada Jagung. Penelitian Pertanian Tanaman Pangan 33(2):129-135.

Surtikanti. 2013. Cendawan Peronosclerospora sp. Penyebab Penyakit Bulai di Jawa Timur. Seminar Nasional Invasi Teknologi Pertanian. Banjarbaru. 26-27 Maret 2017.

Uruilal, C. Kalay, A. M., Kaya, E., dan Siregar, A. 2012. Pemanfaatan Kompos Ela Sagu, Sekam dan Dedak Sebagai Media Perbanyakan Agens 
Hayati Trichoderma harzianum Rifai. Jurnal Agrologia 1 (1): 21-30.

Wakman, W. dan Said, M. K. 1986. Penggunan Fungisida Ridomil untuk Pengendalian Penyakit Bulai pada Tanaman Jagung di Sulawesi Selatan. Agrikam 1 (2): 41-44.
Yulia, E., Istifadah, N., Widiantini, F., dan Utami, H.S. 2017. Antagonisme Trichoderma spp. Terhadap Jamur Rigidoporus lignosus (klotzsch) imazeki dan Penekanan Penyakit Jamur Akar Putih pada Tanaman Karet. Jurnal Agrikultura 28(1):47-55. 